\title{
FISCAL EXPANSIONS AND FISCAL ADJUSTMENTS IN OECD COUNTRIES
}

\author{
Alberto Alesina \\ Roberto Perotti
}

Working Paper No. 5214

\author{
NATIONAL BUREAU OF ECONOMIC RESEARCH \\ 1050 Massachusetts Avenue \\ Cambridge, MA 02138 \\ August 1995
}

Prepared for the Economic Policy Panel, April 1995. We thank Francesco Giavazzi, Guido Imbens, Fabio Schiantarelli and Charles Wyplosz for useful comments and suggestions. We are particularly grateful to Marianne Fay for providing some data and for several helpful conversations. Our debt towards her goes beyond the usual acknowledgement: she was part of "the team" when we started this project, and discussed with us several ideas, but other commitments made it impossible for her to participate in the project. We thank Roberta Gatti for excellent research assistance. This paper is part of NBER's research program in Monetary Economics. Any opinions expressed are those of the authors and not those of the National Bureau of Economic Research.

() 1995 by Alberto Alesina and Roberto Perotti. All rights reserved. Short sections of text, not to exceed two paragraphs, may be quoted without explicit permission provided that full credit, including $\odot$ notice, is given to the source. 


\title{
FISCAL EXPANSIONS AND FISCAL
} ADJUSTMENTS IN OECD COUNTRIES

\begin{abstract}
This paper considers budget expansions and adjustments in OECD countries in the last three decades. Our main results are: i) on average fiscal expansions are the results of increases in expenditures, particularly of transfer programs, while contractions are typically due to tax increases; ii) however successful (i.e. long lasting), a minority of the total rely primarily on reduction of government wages and employment and cuts in transfer programs; iii) even major successful fiscal adjustments do not seem to have recessionary consequences, on average; iv) different types of governments show different degrees of success at implementing successful fiscal adjustment, with coalition governments showing the worst performance.
\end{abstract}

Alberto Alesina Department of Economics Harvard University Cambridge, MA 02138 and NBER
Roberto Perotti

Department of Economics

Columbia University

420 West 118th Street

New York, NY 10027 


\section{Introduction.}

\subsection{The questions.}

Following the first oil shock, in the mid-seventies many OECD countries started accumulating large public debts; by 1990, several countries exhibited debt/GDP ratios at levels historically observed after major wars, in some case beyond 100 percent (see Table 1). At the same time, the composition of government outlays underwent a major shift (see Table 2): while thirty years ago the largest fraction of government spending was "purchase of goods and services", currently in many countries transfer programs are quantitatively the single most important item of the budget.

These two tables viewed together suggest that there might be a relationship between the budget balance and the budget composition. Also, as a result of these two trends, it, is becoming increasingly apparent that cuts in the "welfare state" will have to be a critical part of the necessary fiscal adjustments.

The standard macroeconomic literature on fiscal policy generally ignores issues of composition of the budget. In fact, in the majority of macroeconomic models government spending is viewed as "purchase of goods and services", a component which is becoming less and less important empirically. ${ }^{1}$ From a policy perspective, instead, changes in the composition of the budget are extremely important. When a policymaker must improve the budget balance, he can raise taxes and/or cut expenditures. But which of the two sides should be used? Which component of expenditure can and should be cut? Which taxes should be raised?

The first question which we address is the relationship between the fiscal stance, i.e., loose or tight budget balance, and the composition of expenditures and revenues. We discuss whether fiscal expansions and fiscal adjustments rely on specific items of the budget more than on other items.

The second, related, question is whether the composition of fiscal adjustments influences the likelihood of success, defined as a relatively permanent consolidation of the budget. Do successful adjustments rely primarily on expenditure cuts or tax increases? Are cuts in transfer programs and social expenditures a necessary components of successful adjustments?

Third, we ask several politico-economic questions. Which types of government are

\footnotetext{
${ }^{1}$ A partial exception is the "overlapping generations" literature, which focuses on intergenerational transfers, although not explicitly on the composition of the budget. Some of the new political economy literature focuses on the redistributive role of fiscal policy and therefore, indirectly, on budget composition. For a survey of this literature, see Alesina and Perotti (1995).
} 
Table 1: Debt/GDP ratios.

\begin{tabular}{|l|ccc|}
\hline \hline & 1965 & 1975 & 1990 \\
\hline \hline Australia & N.A. & N.A. & 25.53 \\
Austria & $19.37^{\star}$ & 23.94 & 56.43 \\
Belgium & 67.49 & 61.06 & 131.18 \\
Canada & 58.79 & 43.09 & 71.91 \\
Denmark & 11.30 & 11.92 & 59.46 \\
Finland & 17.70 & 8.57 & 16.77 \\
France & $53.05^{\star}$ & 41.08 & 46.64 \\
Germany & 17.34 & 25.08 & 43.58 \\
Greece & 14.15 & 22.43 & 88.73 \\
Ireland & N.A. & 64.37 & 101.74 \\
Italy & 35.41 & 60.40 & 100.48 \\
Japan & .07 & 22.41 & 69.76 \\
Netherland & 52.21 & 41.38 & 76.12 \\
Norway & $47.02^{\star}$ & 44.75 & 39.12 \\
Portugal & N.A. & N.A. & N.A. \\
Spain & N.A. & N.A. & 46.81 \\
Sweden & 30.48 & 29.52 & 44.23 \\
Switzerland & N.A. & N.A. & N.A. \\
U.K. & $81.77^{\star}$ & 63.73 & 34.67 \\
U.S. & 52.10 & 42.69 & 56.22 \\
\hline \hline
\end{tabular}

Source: OECD. Debt is gross. ${ }^{\star}: 1970$. 
Table 2: Government consumption and transfers, as shares of GDP.

\begin{tabular}{|l|cccc|}
\hline \hline & $\begin{array}{c}\text { govt. cons. } \\
1965\end{array}$ & $\begin{array}{c}\text { transf. } \\
1965\end{array}$ & govt. cons. & transf. \\
\hline \hline Australia & 12.71 & $\mathrm{NA}$ & 17.24 & 1990 \\
Austria & 13.36 & 14.93 & 17.79 & 20.19 \\
Belgium & $13.68^{\star}$ & $14.61^{\star}$ & 15.13 & 20.49 \\
Canada & 14.38 & 6.17 & 20.03 & 13.19 \\
Denmark & 16.41 & 6.98 & 25.22 & 20.50 \\
Finland & 13.66 & 7.61 & 21.05 & 12.28 \\
France & 14.36 & 15.70 & 17.92 & 23.30 \\
Germany & 15.20 & 13.71 & 18.38 & 19.53 \\
Greece & 11.72 & 6.89 & 21.08 & 14.59 \\
Ireland & 14.37 & $\mathrm{NA}$ & 17.20 & 14.31 \\
Italy & 14.54 & 12.65 & 17.41 & 19.16 \\
Japan & 8.18 & 4.93 & 9.14 & 12.03 \\
Netherland & $15.40^{\star}$ & $16.41^{\star}$ & 14.47 & 27.85 \\
Norway & 15.05 & 9.13 & 21.03 & 20.61 \\
Portugal & 12.28 & 3.53 & 16.73 & 13.24 \\
Spain & 8.47 & 6.25 & 15.47 & 15.92 \\
Sweden & 17.76 & 9.87 & 27.36 & 21.52 \\
Switzerland & 16.68 & 7.70 & 19.97 & 12.10 \\
U.K. & 19.39 & 5.85 & 18.89 & 12.28 \\
U.S. & 10.64 & 9.14 & 13.65 & 17.37 \\
\hline & & & & \\
\hline
\end{tabular}

Source: OECD. ${ }^{\star}: 1970$. 
more likely to follow loose or tight fiscal policies? Are coalition governments or single party governments more likely to accomplish successful adjustments? Are there significant differences between left wing and right wing governments? Are loose policies typically followed in an election year?

The final set of questions concerns the macroeconomic consequences of fiscal adjustments. Do they cause major recessions? Do they crowd in private investments? Do they improve competitiveness?

In addressing all these questions we choose a very simple approach. But even our simple data analysis paints a clear general picture.

\subsection{The answers.}

First of all, we find important asymmetries between loose and tight fiscal policies. On average, loose policies are the result of sharp increases in government expenditure, particularly transfer programs; conversely, tight policies are carried out through increases in taxes, particularly direct taxes on households, rather than through reductions in expenditure.

However, and this is our second major conclusion, this last result on the average adjustment hides a fundamental difference between successful and unsuccessful adjustments. Successful adjustments (a minority of the total) rely mostly on cuts in transfer programs and in government wages and employment. Unsuccessful adjustments rely primarily on increase in taxes, leaving transfer programs and government wages and employment untouched, or even increased.

Third, in comparing single party governments and coalition governments, we find that the latter are incapable of achieving a stable consolidation of the budget. They often try but systematically fail. On the other hand, we do not find much difference between left wing and right wing single party governments in their ability to implement success adjustments.

Finally, there is no evidence that "hell breaks loose" during or after strong fiscal adjustments. Actually, if the adjustment is carried out in a way that ensures it will have lasting effects, growth, investment and competitiveness increase, in some cases quite drastically. Only ill-conceived, unsuccessful fiscal adjustments lead to a deterioration of the economic environment.

\subsection{Relationship with the literature.}

Our paper is related to four lines of work. The first is the literature on fiscal adjustments which includes, for instance, Alesina (1989), Dornbusch (1989), Giavazzi and Paganu (1990), amongst others. Relative to these papers we emphasize more compositional issues, 
we follow a more disaggregated approach and we do not use a case study method but, instead, statistical evidence. A recent paper by deHaan, Sterks and deKam (1992) discusses not only fiscal adjustments, but more generally, the evolution of fiscal policy (both on the expenditure side and on the taxation side) in Europe. While we share with that paper an emphasis on compositional issues, we have a less broadly descriptive and more specific purpose in mind.

The second line of research we relate to is the empirical work which studies whether budget deficits are primarily the result of increases in aggregate expenditure or cuts in aggregate taxation. For instance, Bohn (1992) addresses this issue with specific reference to the United States. While we touch upon this issue as well, our goal in this paper is much broader: first, we emphasize the composition of expenditure and taxation, not only their aggregate levels; second, we analyse several other important issues; third, our analysis covers almost all OECD countries.

The third line of work that is somehow connected to ours is the research on the political economy of budget deficits, which we recently surveyed in Alesina and Perotti (1995). In particular, we touch upon issues related to empirical results by Roubini and Sachs (1989a,b) and Grilli, Masciandaro and Tabellini (1991) on the effects of coalition governments on the budget balance. These authors study the effects of different types of government on debt; we emphasize more the propensity to initiate fiscal adjustments and their likelihood of success. We also relate, in part, to the literature on political business cycles, (see Alesina (1993) for a survey) and, specifically, on the effects of the electoral cycle un fiscal policy, an issue recently addressed empirically for OECD countries by Alesina, Cohen and Roubini $(1992,1993)$.

Finally, in defining our measure of discretionary fiscal policy we refer to the literature on how to 'adjust' standard measures of budget balance for the cycle. We found Blanchard (1993) particularly illuminating on this point. Also, McKenzie (1993) provides a very useful broad discussion of the literature.

\subsection{Summary.}

This paper is organized as follows. Section 2 discusses alternative measures of discretionary fiscal policy. We describe the measure which we use throughout the paper. Section 3 discusses the behavior of aggregate expenditure and taxation in periods of loose and tight fiscal policy. Section 4 continues this analysis by disaggregating expenditures and taxes in several components. Section 5 provides a definition of successful versus unsuccessful fiscal adjustments and identifies several features which differentiate them. In section 6 we study the robustness of our results, along several dimensions. Section 7 addresses 
politico-economic questions, asking, in particular, which types of government are more likely to implement successful adjustments. Section $8 \mathrm{~s}$ investigates some macroeconomic implications of major expansions and adjustments. The last section concludes.

\section{The fiscal impulse.}

\subsection{The discretionary component of fiscal policy.}

In this paper, we are mainly interested in those changes in fiscal policy that result from intentional actions by the policymakers; we are less interested in those changes that derive from the effect of the economic cycle on expenditure and tax revenues.

We define the fiscal impulse as the discretionary change in the budgetary position of the government. Roughly speaking, the fiscal impulse is the difference between some actual measure of the budgetary position of the government and the level of the same measure that would prevail if the effects of the cycle could be partialled out by referring to some benchmark situation.

Unfortunately, there is no universally accepted method of defininig what part of the current budgetary position reflects an exogenous action on the part of the government and what part is merely a reflection of the cycle. Schematically, there are two types of problems: (i) How to define the benchmark situation to be used to adjust the actual measure? (ii) What parts of the budget should be adjusted to this benchmark, and how? For instance, should interest payments be adjusted for inflation, and how?

Addressing the first problem involves taking a stance on controversial conceptual and statistical issues. For instance, how to estimate potential output, to be used, in conjunction with Okun's law, to adjust the value of several expenditures sensitive to the cycle, like unemployment benefits? Addressing the second problem presents difficulties that are more practical in nature. For instance, to adjust unemployment benefits one would ideally need rather detailed information on replacement ratios. More generally, one would need a set of elasticities of the various types of taxes and expenditures to income, unemployment and inflation.

In addition to these widely acknowledged issues, some authors, in particular Buiter (1983, 1985), have argued that a proper measure of the deficit and of the fiscal stance should take into account all changes in the public sector net worth. Thus, according to Buiter a "standard" cyclical adjustment of the deficit measure would not be enough. ${ }^{2}$

In our view, a useful measure of the fiscal stance must be simple, even at the cost of

\footnotetext{
${ }^{2}$ See McKenzie (1988) for more discussion on this point
} 
ignoring relatively important considerations. Fortunately, for our purposes, simplicity does not come at a high price. First, we are only interested in changes in the budgetary position of the government. Therefore, for any year the benchmark can be safely assumed to be the previous year. This avoids the problem of choosing a base year when actual output was supposedly at its potential level. Second, we largely take care of the inflation-adjustment problem by excluding interest payments from our measures of the budgetary position of the government. Third, we focus on "large" changes in the budgetary position, such that are unlikely to be caused by purely cyclical factors.

Table 3 describes four widely used measures of the fiscal impulse. It is worth mentioning at the outset that the qualitative conclusions of our analysis are not sensitive to the choice of the measure, as we show in section 6 .

Table 3: Fiscal impulse measures.

\begin{tabular}{|l|l|}
\hline \hline 1. $\triangle$ PRIMARY: & $\mathrm{FI}=\left(g_{t}-t_{t}\right)-\left(g_{t-1}-t_{t-1}\right)$ \\
2. THE BLANCHARD MEASURE: & $\mathrm{FI}=\left(g_{t}\left(U_{t-1}\right)-t_{t}\right)-\left(g_{t-1}-t_{t-1}\right)$ \\
3. THE OECD MEASURE: & $\mathrm{FI}=\left[\left(G_{t}-T_{t}\right)-\left(G_{t-1}\left(1+\hat{y}_{t}\right)-T_{t-1}\left(1+y_{t}\right)\right)\right] / Y_{t-1}$ \\
4. THE IMF MEASURE: & $\mathrm{FI}=\left[\left(G_{t}-T_{t}\right)-\left(G_{0}\left(1+\hat{y}_{t}\right)-T_{0}\left(1+y_{t}\right)\right)\right] / Y_{t-1}$ \\
\hline
\end{tabular}

$G_{t}$ : total current expenditure plus gross capital accumulation less interest payments; $T_{t}$ : total revenues. $g_{t}$ and $t_{t}$ represent the same variables, but as shares of GDP. $Y_{t}:$ nominal GDP. $y_{t}$ : rate of growth of nominal GDP. $\hat{y}_{t}$ : rate of growth of nominal potential GDP. $G_{0}$ : value of $G$ in base year, when actual output is equal to potential output. $T_{0}$ : revenues in base year. $U_{t}:$ unemployment rate.

The simplest possible definition of the fiscal impulse is the change in the primary deficit as share of GDP from the previous year, $\triangle P R I M A R Y$. Thus, implicitly this measure takes the previous year as the benchmark year. The great advantage of this measure is its simplicity. Its disadvantage is that it ignores cyclically induced fluctuations in the primary deficit. $^{3}$

Blanchard (1993) suggests a very attractive way of addressing this problem without

\footnotetext{
${ }^{3}$ Note, however, that if the endogenous component of all revenues and expenditures were unit elastic to actual GDP, this measure would identify all and only discretionary changes in fiscal policy. Thus, this measure is not a bad approximation as long as expenditures and revenues are close to being unit elastic to GDP.
} 
sacrificing simplicity. His measure still takes the previous year as the benchmark year, but recognizes that government outlays can be negatively related to GDP, because of built-in stabilizers like unemployment compensation. similarly, revenues can be positively related to GDP, for instance because of the progressivity of the tax system. For both reasons, the deficit tends to rise endogenously during recessions. To correct for this, without at the same time resorting to estimates of potential output of dubious reliability, Blanchard suggests estimating what government outlays and revenues would be in any given year if the unemployment rate had remained the same as in the previous year.

To implement this measure, we followed this procedure. For each country in the sample, we regressed transfers as a share of GDP (TRANSF) on two time trends for 1960-75 and $1976-92$ and on the unemployment rate $(U)$ :

$$
\text { TRANSF } F_{t}=\alpha_{0}+\alpha_{1} T R E N D 1+\alpha_{2} T R E N D 2+\alpha_{3} U_{t}+\epsilon_{t}
$$

We then estimate what transfers would be in period $t$ if unemployment were the same as in the previous year:

$$
T R A N S F_{t}\left(U_{t-1}\right)=\hat{\alpha}_{0}+\hat{\alpha}_{1} T R E N D 1+\hat{\alpha}_{2} T R E N D 2+\hat{\alpha}_{3} U_{t-1}+\hat{\epsilon}_{t}
$$

where the $\hat{\alpha}_{i}$ 's are the estimated coefficients in regression 1 and $\hat{\epsilon}_{t}$ is the estimated residual in the same regression. We follow the same procedure for total revenues $T_{t}$, to obtain $T_{t}\left(U_{t-1}\right)$. Having constructed $T R A N S F_{t}\left(U_{t-1}\right)$ and $T_{t}\left(U_{t-1}\right)$, we can derive the primary deficit that would have prevailed in period thad the unemployment rate been equal to period $t-1$ 's unemployment rate. The measure of the fiscal impulse is then constructed as the difference between this unemployment-adjusted measure of the primary deficit and the previous year's primary deficit.

The third measure, frequently used by the OECD ${ }^{4}$ defines the fiscal impulse as the difference between the current primary deficit and the primary deficit that would have prevailed if expenditure in the previous year had grown with potential GDP and revenues had grown with actual GDP. ${ }^{5}$ This measure can be better understood by starting from the following expression for the cyclically adjusted budget balance $(C A B)$ :

$$
C A B=\left(G_{t}-T_{t}\right)-\left(\hat{g}_{t-1} \hat{Y}_{t}-t_{t-1} Y_{t}\right)
$$

where $\hat{g}_{t-1}$ is the ratio of government expenditure to potential GDP in period $t-1, t_{t-1}$ is the ratio of taxation to actual GDP in period $t-1$, and $\hat{Y}_{t}$ and $Y_{t}$ are potential and actual

\footnotetext{
${ }^{4}$ See, for instance, Chouraqui, Hagenmann and Sartor (1990).

${ }^{5}$ We are not quite sure about the motivation for this asymmetry.
} 
GDP in period $t$, respectively. The OECD measure (also known as the "Dutch measure" of the fiscal impulse) can be obtained by taking the first difference of the $C A B$, and dividing by GDP in period $t-1$. Thus, like the first two measures, the Dutch measure takes the previous year as the benchmark year. Howcver, now the cyclically neutral expenditure is assumed to be unit elastic to potential output while the cyclically neutral taxation is still assumed to be unit elastic to actual output. In our view, the advantage of the Blanchard measure over this one is that the former does not rely on questionable estimates of potential output. Notice also that the OECD measure is sensitive to the rate of inflation, in a rather subtle way. Suppose that all prices increase between period $t-1$ and $t$ by $10 \%$, while all real variables remain constant. Therefore, actual and potential GDP and all nominal expenditures and tax revenues increase by $10 \%$, while all ratios remain constant. Clearly, the discretionary position of the government has not changed. Yet, if the budget is initially in deficit, the fiscal impulse measure will increase, because all nominal expenditures and revenues in both periods $t$ and $t-1$ are divided by GDP in period $t-1$.

The fourth measure, often advocated by the IMF, differs from all the others because it assumes as the benchmark year not the previous year, but a reference year where potential output was close to actual output. Aside from this difference in the treatment of the benchmark year, this measure (also known as the "German measure" of the fiscal impulse) is similar to the OECD measure illustrated above. A disadvantage of the IMF measure is the degree of arbitrariness in the choice of the base year.

Because of its greater simplicity, in the remainder of this paper we focus our presentation on results obtained using the Blanchard measure. However, despite their conceptual and practical differences, these measures provide surprisingly similar answers to the questions we investigate in this paper. In fact, in section 6 , we show that the nature of our results does not change when the other three measures are used.

\subsection{Loose and tight fiscal policies.}

In this paper, we study the pattern of changes in the composition of the budget during significant changes in the fiscal position of the government. Thus, not only are we not interested in cyclical fluctuations of the budget balance, but also we want to disregard very small discretionary changes in fiscal policy. Instead, we want to focus on relatively large discretionary fiscal impulses, positive and negative. ${ }^{6}$

Our sample includes yearly observations on expenditure and revenue variables from 1960 to 1992 for 20 OECD countries: Australia, Austria, Belgium, Canada, Denmark,

\footnotetext{
${ }^{6}$ The fact that we focus on large changes also explains why our results are not sensitive to the definition of the fiscal impulse.
} 
Finland, France, Germany, Greece, Ireland, Italy, Japan, Netherlands, Norway, Portugal, Spain, Sweden, Switzerland, UK, and USA. We have a total of 547 observations on our measure of the fiscal impulse, which we label BFI, for "Blanchard Fiscal Impulse". The sample average of $B F I$ is $-.008 \%$ of GDP, with a standard deviation of $1.67 \%$ of GDP. We classify the fiscal stance according to the value of the fiscal impulse, as follows:

Definition 1: the fiscal stance.

\begin{tabular}{l}
\hline In any given year, the fiscal stance is \\
Neutral if $B F I \in(-.005, .005) ;$ \\
Loose or a Small expansion if $B F I \in(.005, .015) ;$ \\
Very loose or a Strong expansion if $B F I \geq .015 ;$ \\
Tight or a Small adjustment if $B F I \in(-.015,-.005) ;$ \\
Very tight or a Strong adjustment if $B F I \leq-.015$. \\
\hline
\end{tabular}

According to this definition, a given year is characterized by a loose fiscal policy if the $B F I$ has a value between $.5 \%$ and $1.5 \%$ of GDP, i.e. if the unemployment-adjusted primary deficit has increased by between $.5 \%$ and $1.5 \%$ of GDP relative to the previous year, and so on.

In defining the cut-off points of Definition 1, we are trading off two opposite requirements. On one hand, we need to make sure that very loose or very tight policies are really different from "business as usual", and that they are not unduly influenced by cyclical factors, despite our correction for unemployment. This consideration would require setting high cut-off points for these policies. On the other hand, in order to have enough power for our tests we need to have a sufficient number of observations for each type of policy. In general we find that our results change in an intuitive way when we experiment with different cut-off points: for instance, if we define very loose or very tight fiscal policies more restrictively, the differences between these policies and "normal" times become larger. ${ }^{7}$

Table 4 provides some summary information on the four types of fiscal policy stances generated by the cut-off points of Definition 1 . Note from column 1 that we have a very similar number of loose and tight cases (124 and 121, respectively) and of very loose and

\footnotetext{
${ }^{7}$ Results on this point are available upon request.
} 
Table 4: Summary statistics on $B F I$.

\begin{tabular}{|l|c|c|c|}
\hline \hline & obs. & average & stand. dev. \\
\hline \hline & & & \\
All & 547 & $-0.008 \%$ & $1.67 \%$ \\
Loose & 124 & $0.93 \%$ & .28 \\
Tight & 121 & $-0.93 \%$ & $.29 \%$ \\
Very loose & 65 & $2.81 \%$ & $1.79 \%$ \\
Very tight & 66 & $-2.61 \%$ & $1.46 \%$ \\
& & & \\
\hline \hline
\end{tabular}

The figures in the last column are the sample standard deviations for each type of fiscal stance.

very tight cases (65 and 66 , respectively). Note also that the cut-off points for strong expansions and strong adjustments correspond closely to the average of the $B F I$ plus or minus one standard deviation, respectively.

Table 5 lists all the cases of strong expansions (column 1) and strong adjustments (column 2) that one obtains by applying Definition 1 to our sample. The table suggests several interesting observations. First, our definition captures quite well some well-known episodes of strong and prolonged fiscal adjustments in the mid 80's, like Denmark and Ireland. Second, note the large number of strong expansions in the period 1974-76, clearly a response to the first oil shock. Third, many countries display a typical "stop and go" behavior, with strong adjustments followed by strong expansions, and viceversa: for instance, Finland in the seventies and Portugal in the eighties. Finally, it is worth emphasizing again that the definition we use focuses on strong expansions and adjustments, and therefore it is not designed to capture periods of progressive deterioration of the budget without major jumps in the discretionary component of fiscal policy. For instance, from 1974 onward Italy shows only two years of major expansion, despite a change in the debt/GDP ratio from about $50 \%$ in 1974 to the current $120 \%$.

One might also argue that the criterion of Definition 1 fails to capture an important difference between countries: an increase in the primary deficit by $1.5 \%$ of GDP may represent a large expansion for Germany, but little more than "business as usual" in, say, Italy. To address this issue, we have computed the mean and standard deviation of the $B F I$ separately for each country, and we have modified Definition 1 as follows 
Table 5: Strong expansions and adjustments.

\begin{tabular}{|l|l|}
\hline \hline \multicolumn{1}{|c|}{ Strong expansions } & \multicolumn{1}{|c|}{ Strong adjustments } \\
\hline \hline Australia: $1975,76,91,92$ & Australia: $1974,77,87$ \\
Austria: 1967,75 & Austria: 1977,84 \\
Belgium: 1975,81 & Belgium: 1982,84 \\
Canada: $1975,82,91$ & Canada: 1981 \\
Denmark: $1975,87,88$ & Denmark: $1983,84,85,86$ \\
Finland: $1963,74,75,78,87,90,91,92$ & Finland: $1964,67,73,76,84,88$ \\
France: $1975,81,92$ & France: 1969 \\
Germany: $1974,75,90$ & Germany: $1969,73,76,89$ \\
Greece: $1981,85,88,89$ & Greece: $1982,86,87,90,91,92$ \\
Ireland: 1978 & Ireland: $1984,87,88,89$ \\
Italy: $1965,71,72,75,81$ & Italy: $1967,74,76,80,89,92$ \\
Japan: 1975 & Japan: 1984 \\
Netherland: 1975,87 & Netherland: 1985,91 \\
Norway: $1970,76,77,86,91$ & Norway: $1979,80,83,84,89,90$ \\
Portugal: $1963,74,75,81,83,87$ & Portugal: $1967,77,80,82,84,89$ \\
Spain: 1982 & Spain: 1986,87 \\
Sweden: $1974,77,79,88,91$ & Sweden: $1971,76,83,84,87$ \\
U.K.: $1971,72,90,91,92$ & U.K.: $1969,77,88$ \\
U.S.: 1967,75 & U.S.: 1969,76 \\
\hline \hline
\end{tabular}


Definition 1bis: the fiscal stance.

Let $\mu_{i}$ and $\sigma_{i}$ be the average and the standard deviations of the change in the unemployment-adjusted primary deficit for country $i$. In any given year, the fiscal stance in country $i$ is Neutral if $B F I \in\left(\mu_{i}-.5 \sigma_{i}, \mu_{i}+.5 \sigma_{i}\right)$; Loose or a Small expansion if $B F I \in\left(\mu_{i}+.5 \sigma_{i}, \mu_{i}+\sigma_{i}\right)$; Very loose or a Strong expansion if $B F I \geq \mu_{i}+\sigma_{i}$; Tight or a Small adjustment if $B F I \in\left(\mu_{i}-\sigma_{i}, \mu_{i}-.5 \sigma_{i}\right)$; Very tight or a Strong adjustment if $B F I \leq \mu_{i}-\sigma_{i}$.

Thus, according to this definition a strong adjustment for a given country is a fall in our unemployment-adjusted measure of the primary deficit by more than one standard deviation from the average change for that country. All our results remain practically unchanged if Definition 1 bis rather than Definition 1 is adopted. In the remainder of the paper, we present results based on Definition 1.

\section{Aggregate expenditures and $t$ i.xation and tie fis- cal stance.}

In this section we ask the question of whether expansions typically are the results of increases in expenditure or cuts in taxation and, similarly, whether adjustments typically occur on the expenditure side or on the tax side.

Table 6 reports sample statistics for our measure of the fiscal impulse, and for its two main components, total expenditure (net of interest payments) and total taxation, under the different types of fiscal stance. ${ }^{8}$

An interesting feature that emerges from this table is that, on average, episodes of strong adjustments are the mirror image of episodes of strong expansions: in fact, the average increase in the adjusted deficit during the former (2.81\% of GDP) is very close,

\footnotetext{
${ }^{8}$ Total expenditure and taxation are not unemployment-adjusted. Evaluating them at the previous year's unemployment rate, however, would not make any difference in our results.
} 
in absolute value, to the average fall during the latter (2.61\%) of GDP). This provides an important ceteris paribus condition for our analysis: specifically, it ensures that any significant asymmetry in the behavior of each particular type of expenditure or taxation between the two fiscal policy stances is due to a genuine qualititative difference in the working of fiscal policy during strong expansions and strong adjustments, and not to different sizes of the change. Similarly, the average fall in the adjusted deficit during small adjustments (.93\% of GDP) is identical to the average increase during small expansions.

Aggregate expenditure (column 3) and aggregate taxation (column 4) also present an important asymmetry. Expansions result mainly from increases in expenditure, adjustments from increases in taxation. This is particularly evident when comparing loose and tight fiscal policies, but also very loose and very tights fiscal policies, although in this last case some adjustment occurs also on the expenditure side as well. These results suggest that increases in expenditure during loose fiscal stances tend to be permanent and set the stage for subsequent tax increases.

A similar picture emerges from the regression analysis of Table 7 . We regress the change of total expenditure and total taxation (as shares of GDP) on three economic controls and the five dummy variables which concern us. The three economic controls are: the change in the rate of inflation $(\Delta I N F)$, the change in the unemployment rate $(\Delta U)$, and the change in the rate of growth of GDP $(\Delta G R)$. The five dummy variables define the fiscal policy impulse in that year: for instance, TIGHT takes the value 1 in periods of tight fiscal policy according to Definition $1 \mathrm{a}$, and similarly for the other dummy variables. The coefficient of each dummy variable therefore indicates by how much the dependent variable - as a proportion of GDP - would change, on average, under each type of fiscal impulse, if the economic determinants were all 0 .

In the expenditure regression, we expect a negative coefficient on $\triangle I N F$; when inflation increases, government expenditure as a share of GDP decreases because in the short run several expenditures are fixed in nominal terms or not perfectly indexed to the price level. We also expect a positive coefficient on $\Delta U$ because of the effects of built-in stabilizers like unemployment insurance, and a negative coefficient on $\Delta G R$ because many expenditures are fixed in advance at some level consistent with an "average" or "long-run" level of income. In the revenue regression, the sign of the coefficient of $\triangle I N F$ is a priori ambiguous. On one hand, a rise in inflation tends to increase income tax revenues relative to GDP because, at the rates of inflation prevailing in OECD countries, the bracket creeping effect arising from imperfect indexation of income tax brackets clearly prevails over the Olivera-Tanzi effect. On the other hand, a rise in inflation tends to decrease the share of social security contributions in GDP, since social security contributions usually are paid only on those parts of the wage below a certain maximum value, which is usually not indexed to the 
price level. Because social security contributions are a sizable share of total revenues, and the largest single source in several countries including France, Germany, the Netherlands, and Spain, this second effect can be quite substantial. In the revenue regression, we also expect a negative coefficient on $\Delta U$ and a positive coefficient on $\Delta G R$ essentially because of the automatic stabilizing features of many taxes.

The coefficients of the economic determinants of expenditure in column (1) of Table 7 have all the expected signs and are highly significant. In column (2), the coefficients of $\Delta U$ and $\Delta G R$ have the wrong sign. This suggests the following explanation: when unemployment increases or growth decreases, governments react by increasing expenditure (relative to GDP); taxation also rises in order to keep up, at least partially, with the increase in expenditure. For instance, during the recession of the mid '70's budget deficits rose everywhere, but in most countries taxation increased relative to GDP.

Our focus is, however, on the remaining five dummy variables. The pattern of the coefficients clearly confirms the results of Table 6. Expansions are very much the mirror image of adjustments: during expansions, most of the action is on expenditure, while during adjustments, it is on taxation. In fact, the coefficient of LOOSE in column (1) is almost identical to the coefficient of TIGHT in column (2); on average, total expenditure during small expansions and total taxation during small adjustments increase by the same amount, about $.85 \%$ of GDP. On the other hand, both the coefficient of $T I G H T$ in column (1) and of $L O O S E$ in column (2) are practically 0.

A similar pattern emerges from a comparison of very loose and very tight episodes. In this case some adjustment in very tight years occurs also on the spending side, but the adjustment on the taxation side is considerably larger. In very loose years cuts in taxes are about one quarter of increases in expenditures.

One may argue that the economic controls are clearly endogenous and, particularly for the case of inflation, one may worry about reverse causation. We have two answers to this legitimate concern. First, even assuming that the estimates of all coefficients are biased as a result of this endogeneity problem, there is no reason why this bias should affect, say, the TIGHT dummy variable differently for expenditure and taxation regressions. In other words, it is difficult to imagine why reverse causality should induce the asymmetry in the estimated coefficients of the fiscal stance dummy variables in columns (1) and (2). Second, the coefficients of the fiscal stance dummy variables in Table 7 imply average changes that are very close to the sample averages displayed in Table 6 . This suggests that the effects of unemployment, inflation, and growth are not of primary importance.

The main findings of this section can be summarized as follows:

I.1) The average increase in the unemployment-adjusted primary deficit during expansions $(B F I)$ is very close to the average fall during adjustments. 
I.2) Expansions are mostly the result of increases in expenditure; adjustments are mostly the result of increases in taxation.

Next, we disaggregate total expenditure and taxation and analyse how their individual components behave in the different types of fiscal stance.

\section{Disaggregating expenditure and taxation.}

For each of the different types of policy stance, Table 8 reports the average changes of five different components of government expenditure, expressed as shares of GDP: public investment (IG), transfers (TRANSF), non-wage government consumption (CGNW), government wages (CGW) and subsidies (SUB). An important pattern emerges. During periods of loose and very loose fiscal policy, it is mainly transfers and government wages that increase. During tight and very tight fiscal policies, cuts in expenditure (which, remember, are a small part of the adjustment) fall primarily on public investment.

The average increase in transfers during loose and particularly, very loose years is quite remarkable. In the latter case transfers increase by more than 1 percent of GDP! Government wages also increase substantially during very loose years, by more than one half of a point of GDP. By contrast, government transfers and wages fall only slightly during very tight years. The share of non wage government consumption (together with subsidies) shows the least interesting and significant movements. Paradoxically, government consumption typically receives the most attention in the academic debate on the macroeconomic effects of fiscal policy.

Interesting compositional effects emerge also on the taxation side, although now the pattern is slightly less clear-cut. Table 9 presents a breakdown of revenues. In expansions, it is direct taxes on businesses and indirect taxes that are cut. During adjustments, indirect taxes and especially direct taxes on households increase. Social security contributions have a "life of their own" somewhat unrelated to the overall stance of fiscal policy. In particular, social security contributions increase significantly during expansions. This suggests that the contemporaneous increase in social expenditure makes increases in social security contributions more politically acceptable.

The main messages of Tables 8 and 9 can be summarized as follows:

II.1) On the expenditure side, there is an important asymmetry between adjustments and expansions: the former are implemented mainly through cuts in public investment and subsidies, with practically no cuts in transfers. The latter are implemented via large increases in transfers and wage government consumption.

II.2) Similarly, on the revenue side, there is an asymmetry between adjustments and expansions: during the former, personal and corporate income taxation increase the most. 
During the latter, indirect taxes and corporate income taxes fall the most, while cuts in personal income taxes are never important.

II.3) Non-wage government consumption is never a primary factor during episodes of changes in the fiscal policy stance. In particular, very loose fiscal policies are engineered through much bigger changes in transfers and wage government consumption than nonwage government consumption.

\section{Successful and unsuccessful adjustments.}

Presumably, governments incur the econonic and political costs of implementing strong adjustments in order to correct for excessive existing deficits and debts. It is then important to investigate how successful strong adjustments have been in correcting these fiscal problems on a permanent basis. Therefore, we want to isolate episodes of very tight fiscal policy which have led to a "long run" consolidation of the budget, as opposed to episodes which have soon been reversed. We face two data constraints in picking the criterion. First, in order to define a success, we cannot look very far into the future after the year in which the strong adjustment occured, since most adjustments take place in the mid - late eighties. Second, if we impose very high standards in defining a success we are left with very few observations.

We have tried with several different definitions. In the text we present results obtained using Definition 2 below. As we show in section 6 , our results are quite robust to changes in the definition.

\section{Definition 2: successful adjustments.}

A successful adjustment in year $t$ is defined as a "very tight" fiscal stance in year $t$ such that the gross debt/GDP ratio in year $t+3$ is at least 5 percentage points of GDP lower than in year $t$.

In our sample we have 14 successful adjustments and 38 unsuccessful ones. ${ }^{9}$ Table 10 shows that the average fall in the fiscal impulse $(B F I)$ as a percentage of GDP is 2.18

\footnotetext{
${ }^{9}$ The sum of successful and unsuccessful adjustments, 52 , is less than the total of very tight fiscal
} 
for unsuccessful adjustments, and 2.74 for successful ones. Thus, successful adjustments are slightly larger, but not very much. In other words, it appears that it is not the size of the adjustment that sets aside successful ones from unsuccessful ones. On the contrary, we argue below that it is the composition of the adjustment that makes an adjustment successful.

First, Table 10 shows that, while in successful adjustments almost all the action comes from expenditure cuts, in unsuccessful ones almost all the action comes from an increase in taxes. In successful cases, about 80 percent of the adjustment is on the expenditure side. In unsuccessful ones the size of tax increases is more than three times the size of expenditure cuts.

Second, Table 11 shows striking asymmetries on the expenditure side. In successful adjustments, the lion's share of the cuts is on transfers and government wages. Each of these categories is cut more than one half percent of GDP, for a total of about 1.15 percent, a rather large amount for this kind of go:ernment outlays, typically thought of as politically too sensitive to be touched. By contrast, in unsuccessful adjustments the change in transfers and government wages is minimal, and insignificantly different from 0 . Rather, public investment falls by as much as all other expenditures combined.

This is one of the most important results of the paper. It sends a rather clear message to the policy maker: any serious fiscal adjustment hoping to be successful, cannot avoid dealing with cuts in the welfare state and in government wages and employment.

Further evidence specifically on government employment is highlighted in Table 12. The two columns display the average change in government employment as a share of the labor force (column (1)), and as a share of total employment (column (2)), under the different types of fiscal stance. Public employment tends to increase always, except during very tight fiscal policies. Within the latter, however, there is a fundamental difference between successful and unsuccessful adjustments: during the former, the share of public employment, both in the labor force and in total employment, remains essentially constant. During the latter, it increases at about the same rate as the whole sample average.

Table 13 shows the composition of tax increases in successful and unsuccessful adjustments. That limited part of successful adjustments that is due to increases in taxes comes mainly form direct taxes on business. During unsuccessful adjustments, direct taxes on households and indirect taxes are increased substantially. Note that, once again, social security contributions behave opposite to the other types of taxes. ${ }^{10}$

policies, 68, because 16 epsiodes of very tight fiscal stance occurred between 1990 and 1992 , and therefore cannot be classified as successful or unsuccessful according to our criterion.

${ }^{10}$ Alesina and Perotti $(1994,1995)$ show that, in a sample of 14 OECD countries, increases in income taxes on households and in indirect taxes lead to a significant loss of competitiveness. The mechanism is as 
In summary, the results of this section are quite clear cut. We can summarize them as follows:

III.1) Successful and unsuccesful adjustments imply, on average, the same fall in the unemployment-adjusted defiict. However, the former rely mostly on expenditure cuts; the latter, on tax increases.

III.2) Within expenditure, successful adjustments are characterized by large cuts in transfers and in wage government consumption. The limited expenditure cuts that occur during unsuccessful adjustments come mainly from government investment.

\section{Robustness of the results.}

In this section, we investigate how robust our results are, along several dimensions. First, the definition of the fiscal impulse; second, the use of actual GDP to deflate fiscal variables; third, the stringency of the criterion in Definition 2 to determine a successful adjustment; fourth, the criterion itself used to define a successful adjustment. To save space, in each case we only report the changes in the various types of expenditures in successful and unsuccessful adjustments. Hence, the tables that follow should be compared to Table 11 .

As we discussed in section 2, there are several possible ways to define the fiscal impulse. Table 14 reports the results when the OECD measure of the fiscal impulse is used. The only substantial difference is that now transfers fall by much less during successful adjustments. However, they also increase substantially during unsuccessful adjustments, so that in the end the difference between the two types of fiscal stance, $.38 \%$ of GDP, is close to that of Table $11, .52 \%$ of GDP.

Next, in Table 15 we deflate all nominal variables using the potential GDP rather than the actual GDP. ${ }^{11}$ The rationale for doing this is that in a recession the ratio of government expenditure to GDP may increase not because of an intentional action on the part of the policymaker, but because the denominator falls. As one can see, the differences are minimal.

One would expect that, as the stringency of the criterion used to define a successful adjustment falls, the difference between successful and unsuccessful episodes should fall too. In Table 16, we define a successful adjustment as a very tight fiscal policy such that the debt/GDP ratio after three years is below the debt/GDP ratio at the time of the strong

follows: in unionized labor markets with imperfectly competitive firms, increases in income taxes translate into additional wage pressure from the unions, which translates into higher prices of both tradable and nontradable goods, and of exportables relative to importables. Similar effects in the cost side of firms are caused by increases in social security contributions.

${ }^{11}$ We thank Francesco Giavazzi for this suggestion. 
adjustment. ${ }^{12}$ As expected, all government expenditures during successful episodes fall by less than in Table 11, although the difference with respect to unsuccessful episodes remains substantial and significant.

Finally, in Table 11 we defined a successful adjustment with reference to the subsequent fall in the debt/GDP ratio. But another dimension of the success of a very tight fiscal policy is its impact on the budget deficit. Thus, in Table 17 we define an adjustment successful if either the debt/GDP ratio after three years has fallen by at least $5 \%$ of GDP, or the average deficit in the next three years is below the initial defiict by at least $1.5 \%$ of GDP. Because this criterion is easier to satisfy than that of Definition 2, again one would expect the difference between successful and unsuccessful adjustments to fall. Indeed, as before the average fall of all types of expenditures is now slightly smaller than in Table 11, but once again the difference between successful and unsuccessful adjustments is large and significant.

Overall, our main results are robust to various perturbations in the way we define adjustments and success.

\section{Political determinants of fiscal expansions and ad- justments.}

Which types of government are more likely to engage in strongly expansionary fiscal policies, and which types are more likely to carry out successful fiscal adjustments?

We classify governments along two dimensions. First, we distinguish between single party, coalition and minority governments. Second, we compare right-wing, center and left-wing governments. Table 18 summarizes our results. Columns (2) and (3) suggest that coalition governments have a slightly higher tendency to engage in very expansionary fiscal policies. Somehow surprisingly, coalition governments and especially minority governments also have a high propensity to engage in very tight fiscal policies. As regards minority governments, this finding can probably be explained by the fact that they include also caretaker governments, that are often given a specific mandate to clean up fiscal policy before a political government takes over.

The striking difference appears in columns (4) and (5), which distinguish between successful and unsuccessful adjustments. Coalition governments are almost always unsuccessful in their adjustment attempts. Out of 23 strong adjustments initiated by coalition governments, only 2 were successful, which corresponds to a success rate of only $8.7 \%$.

\footnotetext{
${ }^{12}$ Recall that in Definition 2 we required that the debt/GDP ratio after three years be at least five percentage points below the initial one.
} 
By comparison, the success rates of single-party governments and minority governments is $64.3 \%$ and $53.3 \%$, respectively.

These results are generally consistent with the empirical findings of Roubini and Sachs (1989a,b) and Grilli, Masciandaro and Tabellini (1991); these authors find that coalition governments follow looser fiscal policies than single party governments. Our results have a different emphasis: we show that coalition governments do try to be fiscally responsible but they are unable to implement the types of policies needed to make the adjustment last. As we showed in section 5, substantial cuts in social expenditure and in government employment seem to be a prerequisite for a lasting adjustment. However, these are precisely the two types of expenditure that coalition governments are least likely to be able to cut.

The next three lines of Table 18 illustrate the fiscal performance of right-wing, centrist and left-wing governments. Two interesting results emerge. First, left-wing governments are actually far more likely to carry out a a very tight fiscal policy than the other two types of gobvernment. Second, centrist governments are much more prone to engage in very loose fiscal policies, and when they try a strong adjustment they seem to be completely unable to do what it takes to succeed: their success rate is 0 , out of 6 attempts. A possible explanation is that centrist governments are typically coalition governments of (moderate) right wing and left wing parties.

Common wisdom has it that, for obvious reasons, the budget is particularly vulnerable in election years and in recession years. We investigate these issues in the next two tables. The first two lines of Table 19 display the probability that a governutunt engage in very tight and very loose fiscal policies in election and non-election years. As one can see, these probabilities are very similar. Also very similar are the probabilities of success in election and non-election years, as displayed in the last two lines.

We define a recession as a year when the rate of growth of GDP is at least $1 \%$ below the average of the previous two years. Table 20 shows that governments are three times more likely to initiate a very loose fiscal policy in recession years than in non-recession years. Conversely, during a recession governments are about 2.5 times less likely to carry out a strong adjustment. The last two lines of Table 20 show that very tight fiscal policies initiated in non-recession years are twice as likely to be successful than those initiated during recessions. This finding makes intuitive sense: the key ingredients to successul adjustments are cuts in transfer programs and in public employment, precisely the two types of spending cuts that are politically very costly during a recession.

We can summarize the main results of this section as follows:

IV.1) Coalition governments are as likely as other governments to try very tight fiscal policies. However, they seem to be unable to carry out the types of expenditure cuts that are needed to amke a strong fiscal adjustment long-lasting. As a result, their success rate 
is drastically lower than that of both minority and single-party governments.

IV.2) Closeness to elections does not influence the likelihood of strong adjustments, nor their success rates. However, it is much harder to initiate a successful fiscal adjustment during a recession than during an expansion.

\section{The economics effects of expansions and adjust- ments.}

So far we have focused on how expansions and adjustments are carried out and what are their main political determinants. An interesting and important issue is what are their economic consequences. Of course, we do not even try to analyse this question in a systematic fashion. Rather, we focus here on two specific aspects, that we feel our framework is well-equipped to address. First, possibly the single most important reason why it is so difficult to carry out a fiscal reform is the fears of its costs in terms of growth and unemployment. In Table 21 we therefore study whether our sample justifies these fears. Second, most of the policy debate on budget deficits focuses on their crowding-out effects on investment and competitiveness. We present the evidence on this point in Table 22.

The first panel of Table 21 presents our evidence regarding the growth performances of countries that engaged in very loose and very tight fiscal polcies. In the first three columns, we focus on the difference between a country's rate of growth and the (weighted) average rate of growth of the G-7 countries. For instance, the first line displays the average of this difference in the two years before, in the year during, and in the two years after a very loose fiscal policy.

There are two interesting findings here. First, on average very tight fiscal policies tend to be initiated when the country is doing well relatively to the other, while the opposite is true for very loose fiscal polcies. This is consistent with the results of the previous table. Second, there is a dramatic difference between successful and unsuccessful adjustments in their growth performances following the adjustment. The former grow $1 \%$ faster than the G-7 countries. The latter grow $.36 \%$ slower! Importantly, note that on average the years preceding an unsuccessful adjustment display a higher growth than the years preceding a successful adjustment. These conclusions are confirmed by the second panel at the top of Table 21, which presents evidence concerning the average rate of growth (not its difference from the G-7 countries) before, during and after the various types of fiscal stance.

The bottom panel of Table 21 is similar to the top one, except that it focuses on unemployment rather than growth. Here too the evidence is that successful adjustments are accompanied by a fall in unemployment, unsuccessful ones by an increase. In contrast 
to the first panel, however, now on average countries are more likely to engage in a fiscal adjustment when things are bad, and the opposite in the case of an expansion.

In Table 22 we study the effects of strong expansions and strong adjustments on investment and competitiveness. This table supports the crowding-out effects of fiscal policy in the simple IS-LM and Mundell-Fleming models. Investment and competitiveness fall after strong expansions, and increase after strong adjustments. But the table also suggests a new and even stronger effect, which pertains to the difference between successful and unsuccessful adjustments. During the former, business investment as a share of GDP rises by a full $1 \%$ point, while during the latter this share actually falls. Also, competitiveness (defined as the rate of change of unit labor costs, relative to a GDP-weighted average of the unit labor costs of all the other countries of the sample) improves dramatically during and after successful adjustments, while it worsens considerably during and after unsuccessful ones.

The evidence of Tables 21 and 22 is clear-cut and can be summarized in two consclusions.

V.I) As most macroeconomic models would predict, highly expansionary fiscal policies seem indeed to be associated with some crowding out of investment and competitiveness. The opposite is true for highly restrictive fiscal policies.

V.II) Because of their very different compositions, successful and unsuccessful adjustments, although similar in size, have very different effects. The former crowd in investment and competitiveness, and are associated with improvements in growth and employment. The opposite is true for unsuccessful adjustments.

\section{Conclusions.}

In the last three decades cyclically adjusted budget deficits in OECD countries have typically been the result of increases in government spending, particularly on transfer programs and government wages. As public debt increased, interest payments obviously accumulated as well.

Fiscal adjustments that relied primarily on tax increases, especially direct taxes on household, typically failed to permanently stop the growth of public debt. On the contrary, successful adjustments are those that aggressively tackle the expenditure side, particularly the components of it which are always thought of as untouchables: social security and governments wages and employment. The successful adjustment (at least thus far) of Ireland is an excellent example of this. Between 1986 and 1990, transfer programs were cut from $17.6 \%$ of GDP to $14.3 \%$, government employment fell from 307,000 to 269,000 and 
the debt to GDP ratio fell from $120 \%$ to $107 \%$.

Even rather drastic fiscal adjustments are not associated with major recessions, nor with hikes in unemployment. Business investment is crowded in, and competitiveness improves.

Coalition governments are generally unable to carry out successful fiscal adjustments. They often try, but, at least in our sample, never succeed. Our interpretation is that conflicts amongst coalition members and the fragility of coalition governments make it difficult to maintain a "tough" fiscal stance, particularly when politically sensitive programs, government employment and social security are involved.

These results send a rather loud and clear message to policymakers facing the prospect of a fiscal adjustment. There is bad news and good news. The bad news is that one cannot avoid cutting transfers and government employment; quite simply, one cannot achieve permanent results by relying on more politically palatable policies. The good news is that major fiscal adjustments do not cause major recessions. 


\section{References.}

Alesina, A., (1988): "The End of Large Public Debts," in F. Giavazzi and L. Spaventa, eds.,: High Public Debt: The Italian Experience, Cambridge University Press, pp. 34-79.

Alesina, A., (1993): "Elections, Party Structure and the Economy", unpublished.

Alesina, A., G. Cohen, and N. Roubini, (1992): "Macroeconomic Policy and Elections in OECD Democracies," Economics and Politics, Vol. 4, March, pp. 1-30.

Alesina, A., G. Cohen, and N. Roubini, (1993): "Electoral Business Cycles in Industrial Democracies," European Journal of Political Economy, Vol. 23, pp. 1-25.

Alesina, A, and A. Drazen, (1991): "Why Are Stabilizations Delayed?" American Economic Review, Vol. 82, December, pp. 1170-88.

Alesina, A., and R. Perotti, (1995): "The Political Economy of Budget Deficits", IMF Staff Papers, forthcoming.

Alesina A., and N. Roubini, (1992): "Political Cycles in OECD Economies," Review of Economic Studies, Vol. 59, pp. 663-88.

Blanchard, O., (1993): "Suggestions for a New Set of Fiscal Indicators", unpublished.

Bohn, H., (1991): "Budget Balance through Revenue or Spending Adjustments?" Journal of Monetary Economics, 333-359.

Chouraqui, J.C., R. Hagemann and N. Sartcr, (1990): "Indicators of Fiscal Policy, a Reassessment," OECD Working Paper.

DeHaan, J., Sterks, G., and C. deKam (1992): "Toward Budget Discipline: An Economic Assessment of the Possibilities for Reducing National Deficits in the Transition to EMU," EEC Economic Papers.

Dornbusch, R. (1989): "Credibility Debt and Unemployment: Ireland's Failed Stabilization," Economic Policy. 
Emerson, M. (1988): What Model for Europe? MIT Peess.

Giavazzi, F., and M. Pagano (1990): "Can Severe Fiscal Adjustments be Expansionary?" NBER Macroeconomic Annual.

Grilli, V., D. Masciandaro, and G. Tabellini (1991): "Political Monetary Institutions and Public Finance Policies in the Industrial Democracies", Economic Policy, No. 13.

Hughes, G., and S. Smith (1991): "Economic Aspects of Decentralized Government: Structure, Functions and Finance," Economic Policy Vol. 13, (1991).

McKenzie, G. (1988): "Are All Summary Indicators of Stance of Fiscal Policy Misleading?" IMF Staff Papers, December.

Poterba, J. (1994): "State Responses to Fiscal Crises: Natural Experiments for Studying the Effects of Budgetary Institutions" Journal of Political Economy.

Roubini, N., and J. Sachs (1989a): "Political and Economic Determinants of Budget Deficits in the Industrial Democracies", European Economic Review, Vol. 33 (May), pp. 903-33.

Roubini, N. and . Sachs, (1989b): "Government Spending and Budget Deficits in the Industrialized Countries", Economic Policy, Vol. 8 (April 1989), pp. 99-132.

Spolaore, E., (1993): "Policy Making Systems and Economic Efficiency: Coalition Governments versus Majority Governments", unpublished.

Von Hagen, J., (1992): "Budgeting Procedures and Fiscal Performance in the European Community", unpublished. 
Table 6: BFI, aggregate expenditure, aggregate taxation.

\begin{tabular}{|c|c|c|c|c|}
\hline & Nobs. & $\begin{array}{l}B F I \text { avg. } \\
\text { (st. dev.) }\end{array}$ & $\begin{array}{l}\text { Exp. avg } \\
\text { (st. dev.) }\end{array}$ & $\begin{array}{l}\text { Rev. avg. } \\
\text { (st. dev.) }\end{array}$ \\
\hline ALL & 547 & $\begin{array}{l}-.008 \\
(.071)\end{array}$ & $\begin{array}{c}.51 \\
(.058)\end{array}$ & $\begin{array}{c}.42 \\
(.046)\end{array}$ \\
\hline LOOSE & 124 & $\begin{array}{c}.93 \\
(.025)\end{array}$ & $\begin{array}{c}1.04 \\
(.089)\end{array}$ & $\begin{array}{c}.02 \\
(.085)\end{array}$ \\
\hline TIGHT & 121 & $\begin{array}{c}-.93 \\
(.026)\end{array}$ & $\begin{array}{c}.05 \\
(.075)\end{array}$ & $\begin{array}{c}.83 \\
(.072)\end{array}$ \\
\hline $\begin{array}{l}\text { VERY } \\
\text { LOOSE }\end{array}$ & 61 & $\begin{array}{c}2.81 \\
(.230)\end{array}$ & $\begin{array}{c}2.25 \\
(.204)\end{array}$ & $\begin{array}{c}-.17 \\
(.173)\end{array}$ \\
\hline $\begin{array}{l}\text { VERY } \\
\text { TIGHT }\end{array}$ & 68 & $\begin{array}{l}-2.61 \\
(.177)\end{array}$ & $\begin{array}{c}-.79 \\
(.172)\end{array}$ & $\begin{array}{c}1.20 \\
(.166)\end{array}$ \\
\hline
\end{tabular}

Standard errors in parentheses are standard errors of the mean, not of the sample. 
Table 7: Total expenditure and revenues.

\begin{tabular}{|c|c|c|}
\hline & $\begin{array}{l}(1) \\
\text { Exp. }\end{array}$ & $\begin{array}{r}(2) \\
\text { Rev. }\end{array}$ \\
\hline$\triangle I N F L$ & $\begin{array}{c}-.05 \\
(-2.99)\end{array}$ & $\begin{array}{c}-.02 \\
(-1.03)\end{array}$ \\
\hline$\Delta U$ & $\begin{array}{c}.47 \\
(10.04)\end{array}$ & $\begin{array}{c}.15 \\
(3.17)\end{array}$ \\
\hline$\triangle G R O W T H$ & $\begin{array}{c}-.14 \\
(-8.65)\end{array}$ & $\begin{array}{c}-.12 \\
(-7.16)\end{array}$ \\
\hline$N E U T R A L$ & $\begin{array}{c}.27 \\
(3.88)\end{array}$ & $\begin{array}{c}.28 \\
(3.85)\end{array}$ \\
\hline LOOSE & $\begin{array}{c}.81 \\
(9.47)\end{array}$ & $\begin{array}{c}-.06 \\
(-.70)\end{array}$ \\
\hline$T I G H T$ & $\begin{array}{c}.09 \\
(1.03)\end{array}$ & $\begin{array}{c}.86 \\
(9.99)\end{array}$ \\
\hline$V E R Y L O O S E$ & $\begin{array}{c}1.67 \\
(13.24)\end{array}$ & $\begin{array}{c}-.47 \\
(-3.67)\end{array}$ \\
\hline$V E R Y T I G H T$ & $\begin{array}{c}-.73 \\
(-6.43)\end{array}$ & $\begin{array}{c}1.26 \\
(10.90)\end{array}$ \\
\hline nobs & 547 & 547 \\
\hline$R^{2}$ & .53 & .25 \\
\hline see & .93 & .94 \\
\hline
\end{tabular}

OLS. t-statistics in parentheses. 
Table 8: Expenditure averages.

\begin{tabular}{|l|c|ccccc|}
\hline \hline & $\begin{array}{c}E X P \\
\text { (st. dev.) }\end{array}$ & $\begin{array}{c}\text { IG } \\
\text { (st. dev.) }\end{array}$ & $\begin{array}{c}\text { TRANSF } \\
\text { (st. dev.) }\end{array}$ & $\begin{array}{c}\text { CGNW } \\
\text { (st. dev.) }\end{array}$ & $\begin{array}{c}\text { CGW } \\
\text { (st. dev.) }\end{array}$ & $\begin{array}{c}\text { SUB } \\
\text { (st. dev.) }\end{array}$ \\
\hline \hline ALL & .51 & -.03 & .34 & .04 & .13 & .02 \\
& $(.058)$ & $(.014)$ & $(.029)$ & $(.011)$ & $(.018)$ & $(.014)$ \\
\hline LOOSE & 1.04 & .05 & .49 & .15 & .25 & .09 \\
& $(.089)$ & $(.034)$ & $(.055)$ & $(.025)$ & $(.034)$ & $(.028)$ \\
\hline TIGHT & .05 & -.07 & .12 & -.03 & .06 & -.02 \\
& $(.075)$ & $(.023)$ & $(.038)$ & $(.017)$ & $(.031)$ & $(.021)$ \\
\hline VERY & 2.25 & .13 & 1.15 & .26 & .53 & .18 \\
LOOSE & $(.204)$ & $(.039)$ & $(.118)$ & $(.039)$ & $(.068)$ & $(.053)$ \\
\hline VERY & -.79 & -.28 & -.09 & -.14 & -.16 & -.11 \\
TIGHT & $(.172)$ & $(.025)$ & $(.079)$ & $(.029)$ & $(.060)$ & $(.056)$ \\
\hline \hline
\end{tabular}

This table displays the averages of the changes in the GDP shares of total expenditure (exclusive of interest payments) and its main components. IG: government investment. TRANSF: transfers. $C G N W$ : non-wage government consumption. $C G W$ : wage government consumption. $S U B$ : subsidies. 
Table 9: Revenue averages.

\begin{tabular}{|l|c|cccc|}
\hline \hline & $\begin{array}{c}\text { REVEN } \\
\text { (st. dev.) }\end{array}$ & $\begin{array}{c}\text { TYH } \\
\text { (st. dev.) }\end{array}$ & $\begin{array}{c}\text { TYB } \\
\text { (st. dev.) }\end{array}$ & $\begin{array}{c}\text { TIND } \\
\text { (st. dev.) }\end{array}$ & $\begin{array}{c}S S R G \\
\text { (st. dev.) }\end{array}$ \\
\hline \hline ALL & .42 & .16 & .01 & .05 & .19 \\
& $(.046)$ & $(.027)$ & $(.022)$ & $(.023)$ & $(.020)$ \\
\hline LOOSE & .025 & .10 & -.10 & -.11 & .15 \\
& $(.085)$ & $(.062)$ & $(.030)$ & $(.048)$ & $(.034)$ \\
\hline TIGHT & .83 & .27 & .08 & .21 & .24 \\
& $(.072)$ & $(.044)$ & $(.026)$ & $(.037)$ & $(.042)$ \\
\hline VERY & -.17 & -.01 & -.31 & -.13 & .30 \\
LOOSE & $(.173)$ & $(.112)$ & $(.118)$ & $(.085)$ & $(.070)$ \\
\hline VERY & 1.20 & .31 & .36 & .36 & .13 \\
TIGHT & $(.166)$ & $(.093)$ & $(.087)$ & $(.079)$ & $(.075)$ \\
\hline \hline
\end{tabular}

This table displays the averages of the changes in the GDP shares of total revenues (exclusive of interests received) and its main components. TYH: direct taxes paid by households. TYB: direct taxes paid by business. TIND: indirect taxes. SSRG: social security taxes.

Table 10: Successful and unsuccesful adjustments: Total expenditure and revenues.

\begin{tabular}{|l|ccc|}
\hline & $\begin{array}{c}\text { BFI } \\
\text { (st. dev.) }\end{array}$ & $\begin{array}{c}\text { EXPEN } \\
\text { (st. dev.) }\end{array}$ & $\begin{array}{c}\text { REVEN } \\
\text { (st. dev.) }\end{array}$ \\
\hline \hline SUCCESSFUL & -2.74 & -2.19 & .44 \\
ADJUSTMENTS & $(.282)$ & $(.326)$ & $(.385)$ \\
\hline UNSUCCESSFUL & -2.18 & -.49 & 1.28 \\
ADJUSTMENTS & $(.101)$ & $(.188)$ & $(.181)$ \\
\hline \hline
\end{tabular}

This table displays the averages of the $B F I$ measure and of the changes in the GDP shares of total expenditure (exclusive of interest payments) and of total revenues (exclusive of interests received) during successful and unsuccessful adjustments. A very tight fiscal policy in period $t$ is successful if $b y(t+3)-b y(t)<.05$, where $b y$ is the debt/GDP ratio. 
Table 11: Successful and unsuccessful adjustments: composition of expenditure.

\begin{tabular}{|l|c|ccccc|}
\hline \hline & $\begin{array}{c}E X P \\
\text { (st. dev.) }\end{array}$ & $\begin{array}{c}I G \\
\text { (st. dev.) }\end{array}$ & $\begin{array}{c}\text { TRANSF } \\
\text { (st. dev.) }\end{array}$ & $\begin{array}{c}\text { CGNW } \\
\text { (st. dev.) }\end{array}$ & $\begin{array}{c}\text { CGW } \\
\text { (st. dev.) }\end{array}$ & $\begin{array}{c}\text { SUB } \\
\text { (st. dev.) }\end{array}$ \\
\hline \hline SUCCESSFUL & -2.193 & -.41 & -.54 & -.38 & -.58 & -.29 \\
ADJUSTMENTS & $(.326)$ & $(.089)$ & $(.183)$ & $(.055)$ & $(.093)$ & $(.211)$ \\
\hline UNSUCCESSFUL & -.49 & -.26 & -.02 & -.09 & -.07 & -.08 \\
AJUSTMENTS & $(.188)$ & .046 & $(.102)$ & $(.038)$ & $(.071)$ & $(.047)$ \\
\hline
\end{tabular}

See notes to Table 8 . 
Table 12: Government employment.

\begin{tabular}{|l|cc|}
\hline \hline & $\begin{array}{c}E G / L F \\
\text { (si. dev.) }\end{array}$ & $\begin{array}{c}E G / E T \\
\text { (st. dev.) }\end{array}$ \\
\hline \hline ALL & .22 & .28 \\
& $(.016)$ & $(.019)$ \\
\hline LOOSE & .28 & .37 \\
& $(.031)$ & $(.033)$ \\
\hline TIGHT & .19 & .19 \\
& $(.034)$ & $(.038)$ \\
\hline VERY & .35 & .49 \\
LOOSE & $(.061)$ & $(.071)$ \\
\hline VERY & .22 & .24 \\
TIGHT & $(.053)$ & $(.063)$ \\
\hline SUCCESSFUL & .09 & -.007 \\
& $(.159)$ & $(.177)$ \\
\hline UNSUCCESSFUL & .25 & .30 \\
& $(.059)$ & $(.074)$ \\
\hline \hline
\end{tabular}

$E G$ : government employment. $L F$ : labor force. $E T$ : total employment. 
Table 13: Successful and unsuccessful adjustments: composition of revenues.

\begin{tabular}{|l|c|cccc|}
\hline \hline & $\begin{array}{c}\text { REVEN } \\
\text { (st. dev.) }\end{array}$ & $\begin{array}{c}\text { TYH } \\
\text { (st. dev.) }\end{array}$ & $\begin{array}{c}\text { TYB } \\
\text { (st. dev.) }\end{array}$ & $\begin{array}{c}\text { TIND } \\
\text { (st. dev.) }\end{array}$ & $\begin{array}{c}\text { SSRG } \\
\text { (st. dev.) }\end{array}$ \\
\hline \hline SUCCESSFUL & .44 & -.14 & .53 & .17 & -.14 \\
ADJUSTMENTS & $(.385)$ & $(.249)$ & $(.256)$ & $(.119)$ & $(.072)$ \\
\hline UNSUCCESSFUL & 1.28 & .44 & .20 & .43 & .17 \\
ADJUSTMENTS & $(.181)$ & $(.110)$ & $(.052)$ & $(.103)$ & $(.103)$ \\
\hline \hline
\end{tabular}

See notes to Table 8 .

Table 14: Successful and unsuccessful adjustments, OECD fiscal impulse: composition of expenditure.

\begin{tabular}{|l|c|ccccc|}
\hline \hline & $\begin{array}{c}E X P \\
\text { (st. dev.) }\end{array}$ & $\begin{array}{c}I G \\
\text { (st. dev.) }\end{array}$ & $\begin{array}{c}\text { TRANSF } \\
\text { (st. dev.) }\end{array}$ & $\begin{array}{c}\text { CGNW } \\
\text { (st. dev.) }\end{array}$ & $\begin{array}{c}C G W \\
\text { (st. dev.) }\end{array}$ & $\begin{array}{c}\text { SUB } \\
\text { (st. dev.) }\end{array}$ \\
\hline \hline SUCCESSFUL & -1.25 & -.32 & -.13 & -.28 & -.42 & -.10 \\
ADJUSTMENTS & $(.307)$ & $(.090)$ & $(.172)$ & $(.075)$ & $(.129)$ & $(.068)$ \\
\hline UNSUCCESSFUL & .01 & -.25 & .25 & -.06 & -.09 & -.02 \\
ADJUSTMENTS & $(.215)$ & $(.046)$ & $(.113)$ & $(.038)$ & $(.077)$ & $(.042)$ \\
\hline
\end{tabular}

This table is based on the OECD fiscal impulse measure, as defined in Section 2.

Table 15: Successful and unsuccessful adjustments: composition of expenditures as share of potential GDP.

\begin{tabular}{|l|c|ccccc|}
\hline \hline & $\begin{array}{c}\text { EXP } \\
\text { (st. dev.) }\end{array}$ & $\begin{array}{c}I G \\
\text { (st. dev.) }\end{array}$ & $\begin{array}{c}\text { TRANSF } \\
\text { (st. dev.) }\end{array}$ & $\begin{array}{c}\text { CGNW } \\
\text { (st. dev.) }\end{array}$ & $\begin{array}{c}C G W \\
\text { (st. dev.) }\end{array}$ & $\begin{array}{c}\text { SUB } \\
\text { (st. dev.) }\end{array}$ \\
\hline \hline SUCCESSFUL & -1.98 & -.40 & -.40 & -.37 & -.53 & -.28 \\
ADJUSTMENTS & $(.361)$ & $(.090)$ & $(.175)$ & $(.058)$ & $(.103)$ & $(.211)$ \\
\hline UNSUCCESSFUL & -.46 & -.26 & .03 & -.10 & -.07 & -.06 \\
ADJUSTMENTS & $(.182)$ & $(.044)$ & $(.100)$ & $(.036)$ & $(.068)$ & $(.045)$ \\
\hline \hline
\end{tabular}

All variables are divided by potential GDP rather than actual GDP. A very tight fiscal policy in period $t$ is successful if $b y p(t+3)-b y p(t)<.05$ where byp is the debt/potential GDP ratio. 
Table 16: Successful and unsuccessful adjustments, alternative definition: composition of expenditure.

\begin{tabular}{|l|c|ccccc|}
\hline \hline & $\begin{array}{c}E X P \\
\text { (st. dev.) }\end{array}$ & $\begin{array}{c}I G \\
\text { (st. dev.) }\end{array}$ & $\begin{array}{c}\text { TRANSF } \\
\text { (st. dev.) }\end{array}$ & $\begin{array}{c}\text { CGNW } \\
\text { (st. dev.) }\end{array}$ & $\begin{array}{c}C G W \\
\text { (st. dev.) }\end{array}$ & $\begin{array}{c}\text { SUB } \\
\text { (st. dev.) }\end{array}$ \\
\hline \hline SUCCESSFUL & -1.52 & -.35 & -.35 & -.24 & -.33 & -.24 \\
ADJUSTMENTS & $(.295)$ & $(.073)$ & $(.140)$ & $(.063)$ & $(.102)$ & $(.131)$ \\
\hline UNSUCCESSFUL & -.49 & -.25 & .03 & -.11 & -.11 & -.06 \\
ADJUSTMENTS & $(.226)$ & $(.047)$ & $(.122)$ & $(.038)$ & $(.082)$ & $(.055)$ \\
\hline \hline
\end{tabular}

A very tignt fiscal policy in period $t$ is successful if $b y(t+3)-b y(t)<0$, where $b y$ is the debt/GDP ratio.

Table 17: Successful and unsuccessful adjustments, alternative definition: composition of expenditure.

\begin{tabular}{|l|c|ccccc|}
\hline \hline & $\begin{array}{c}E X P \\
\text { (st. dev.) }\end{array}$ & $\begin{array}{c}I G \\
\text { (st. dev.) }\end{array}$ & $\begin{array}{c}\text { TRANSF } \\
\text { (st. dev.) }\end{array}$ & $\begin{array}{c}C G N W \\
\text { (st. dev.) }\end{array}$ & $\begin{array}{c}C G W \\
\text { (st. dev.) }\end{array}$ & $\begin{array}{c}\text { SUB } \\
\text { (st. dev.) }\end{array}$ \\
\hline \hline SUCCESSFUL & -1.74 & -.37 & -.40 & -.27 & -.45 & -.25 \\
ADJUSTMENTS & $(.262)$ & $(.065)$ & $(.137)$ & $(.050)$ & $(.071)$ & $(.143)$ \\
\hline UNSUCCESSFUL & -.43 & -.25 & .03 & -.09 & -.03 & -.09 \\
ADJUSTMENTS & $(.216)$ & .052 & $(.116)$ & $(.043)$ & $(.083)$ & $(.054)$ \\
\hline \hline
\end{tabular}

A very tight fiscal policy in period $t$ is successful if either $b y(t+3)-b y(t)<.05$ or $\frac{1}{3} d e f y(t+3)+\frac{1}{3} d e f y(t+$ $2)+\frac{1}{3} \operatorname{de} f y(t+1)<\operatorname{de} f y(t)-.015$, where by is the debt/GDP ratio and defy is the undemployment-adjusted deficit/GDP ratio. 
Table 18: Political factors.

\begin{tabular}{|l|c|c|c|c|c|}
\hline \hline & $(1)$ & $(2)$ & $(3)$ & $(4)$ & $(5)$ \\
\hline & OBS. & $\begin{array}{c}\text { Prob. of } \\
\text { VERY LOOSE }\end{array}$ & $\begin{array}{c}\text { Prob. of } \\
\text { VERY TIGHT }\end{array}$ & $\begin{array}{c}\text { Prob. of } \\
\text { SUCCESS }\end{array}$ & $\begin{array}{c}\text { Prob. of } \\
\text { NO SUCCESS }\end{array}$ \\
\hline SINGLE & 177 & $8.5 \%$ & $10.2 \%$ & $35.7 \%$ & $64.3 \%$ \\
COAL & 223 & $12.1 \%$ & $13.0 \%$ & $8.7 \%$ & $91.3 \%$ \\
MINOR & 109 & $10.1 \%$ & $15.6 \%$ & $46.7 \%$ & $53.3 \%$ \\
\hline RIGHT & 313 & $8.6 \%$ & $10.9 \%$ & $26.9 \%$ & $73.1 \%$ \\
CENTER & 65 & $15.4 \%$ & $10.8 \%$ & $0.0 \%$ & $100 \%$ \\
LEFT & 129 & $12.4 \%$ & $17.8 \%$ & $35.1 \%$ & $64.9 \%$ \\
\hline \hline
\end{tabular}


Table 19: Elections.

\begin{tabular}{|l|l|l|l|}
\hline \multicolumn{2}{|c|}{ electoral years } & \multicolumn{2}{c|}{ non-electoral years } \\
\hline \hline Prob. of VERY LOOSE & $12.3 \%$ & Prob. of VERY LOOSE & $10.7 \%$ \\
Prob. of VERY TIGHT & $10.4 \%$ & Prob. of VERY TIGHT & $13.3 \%$ \\
Prob. of SUCCESS & $28.6 \%$ & Prob. of SUCCESS & $26.3 \%$ \\
Prob. of NO SUCCESS & $71.4 \%$ & Prob. of NO SUCCESS & $73.7 \%$ \\
\hline \hline
\end{tabular}

Probability of very tight in electoral years: (Number of very tight fiscal stances in electoral years)/(Number of electoral years). Probability of very loose in electoral years: (Number of very loose fiscal stances in electoral years)/(Number of electoral years). Probability of success in electoral years: (Number of successful fiscal stances in electoral years)/(Number of very tight fiscal stances in electoral years). Probability of no success in electoral years: (Number of unsuccessful fiscal stances in electoral years)/(Number of very tight fiscal stances in electoral years). Probabilities in non-electoral years are defined similarly.

Table 20: The business cycle.

\begin{tabular}{|l|c|l|c|}
\hline \hline \multicolumn{2}{|c|}{ recession years } & \multicolumn{2}{c|}{ non-recession years } \\
\hline \hline Prob. of VERY LOOSE & $20.4 \%$ & Prob. of VERY LOOSE & $6.2 \%$ \\
Prob. of VERY TIGHT & $6.8 \%$ & Prob. of VERY TIGHT & $15.4 \%$ \\
Prob. of SUCCESS & $12.5 \%$ & Prob. of SUCCESS & $29.5 \%$ \\
Prob. of NO SUCCESS & $87.5 \%$ & Prob. of NO SUCCESS & $70.5 \%$ \\
\hline
\end{tabular}

Probability of very tight in recession years: (Number of very tight fiscal stances in recession years)/(Number of recession years). Probability of very loose in recession years: (Number of very loose fiscal stances in recession years)/(Number of recession years). Probability of success in recession years: (Number of successful fiscal stances in recession years)/(Number of very tight fiscal stances in recession years). Probability of no success in recession years: (Number of unsuccessful fiscal stances in recession years)/(Number of very tight fiscal stances in recession years). Probabilities in non-recession years are defined similarly. 
Table 21: Growth, unemployment.

\begin{tabular}{|c|c|c|c|c|c|c|}
\hline & \multicolumn{3}{|c|}{$g r-G 7 g r$} & \multicolumn{3}{|c|}{$g r$} \\
\hline & before & during & after & before & during & after \\
\hline VERY LOOSE & $\begin{array}{c}.36 \\
(.250)\end{array}$ & $\begin{array}{c}.59 \\
(.306)\end{array}$ & $\begin{array}{c}-.24 \\
(.222)\end{array}$ & $\begin{array}{c}2.71 \\
(.264)\end{array}$ & $\begin{array}{c}.71 \\
(.380)\end{array}$ & $\begin{array}{c}2.71 \\
(.281)\end{array}$ \\
\hline VERY TIGHT & $\begin{array}{c}.11 \\
(.186)\end{array}$ & $\begin{array}{c}.36 \\
(.295)\end{array}$ & $\begin{array}{c}.05 \\
(.233)\end{array}$ & $\begin{array}{c}2.25 \\
(.205)\end{array}$ & $\begin{array}{c}3.11 \\
(.284)\end{array}$ & $\begin{array}{c}2.55 \\
(.251)\end{array}$ \\
\hline SUCCESSFUL & $\begin{array}{c}.06 \\
(.342)\end{array}$ & $\begin{array}{c}.81 \\
(.537)\end{array}$ & $\begin{array}{c}.99 \\
(.577)\end{array}$ & $\begin{array}{c}2.46 \\
(.465)\end{array}$ & $\begin{array}{c}4.11 \\
(.404)\end{array}$ & $\begin{array}{c}3.23 \\
(.561)\end{array}$ \\
\hline \multirow[t]{2}{*}{ UNSUCCESSFUL } & $\begin{array}{c}.28 \\
(.253)\end{array}$ & $\begin{array}{c}.09 \\
(.373)\end{array}$ & $\begin{array}{c}-.36 \\
(.234)\end{array}$ & $\begin{array}{c}2.28 \\
(.254)\end{array}$ & $\begin{array}{c}3.10 \\
(.370)\end{array}$ & $\begin{array}{c}2.31 \\
(.280)\end{array}$ \\
\hline & before & $\begin{array}{l}-G 7 L \\
\text { during }\end{array}$ & after & before & $\begin{array}{c}U \\
\text { during }\end{array}$ & after \\
\hline VERY LOOSE & $\begin{array}{c}-.21 \\
(.313)\end{array}$ & $\begin{array}{c}-.10 \\
(.345)\end{array}$ & $\begin{array}{c}.09 \\
(.397)\end{array}$ & $\begin{array}{c}4.72 \\
(.375)\end{array}$ & $\begin{array}{c}5.45 \\
(.417)\end{array}$ & $\begin{array}{c}5.66 \\
(.481)\end{array}$ \\
\hline VERY TIGHT & $\begin{array}{c}.73 \\
(.534)\end{array}$ & $\begin{array}{c}.90 \\
(.523)\end{array}$ & $\begin{array}{c}.89 \\
(.558)\end{array}$ & $\begin{array}{c}6.47 \\
(.594)\end{array}$ & $\begin{array}{c}6.63 \\
(.582)\end{array}$ & $\begin{array}{c}6.62 \\
(.596)\end{array}$ \\
\hline SUCCESSFUL & $\begin{array}{c}1.64 \\
(1.50)\end{array}$ & $\begin{array}{c}1.73 \\
(1.45)\end{array}$ & $\begin{array}{c}.98 \\
(1.37)\end{array}$ & $\begin{array}{c}. . j 4 \\
(1.64)\end{array}$ & $\begin{array}{c}7.29 \\
(1.54)\end{array}$ & $\begin{array}{c}6.55 \\
(1.37)\end{array}$ \\
\hline UNSUCCESSFUL & $\begin{array}{c}.41 \\
(.734)\end{array}$ & $\begin{array}{c}.70 \\
(.748)\end{array}$ & $\begin{array}{c}1.11 \\
(.753)\end{array}$ & $\begin{array}{c}6.13 \\
(.822)\end{array}$ & $\begin{array}{c}6.52 \\
(.838)\end{array}$ & $\begin{array}{c}6.84 \\
(.830)\end{array}$ \\
\hline
\end{tabular}

$g r$ : rate of growth. G7gr: weighted average of rates of growth of G-7 countries. $U$ : unemployment rate. $G 7 U$ : weighted average of unemployment rates of G-7 countries. "before": average of the average of the variable over the two years preceding the fiscal policy stance that appears on the column. "during": average value of the variable in the year of the fiscal stance on the column. "after": average of the average of the variable over the two years following the fiscal stance on the column. 
Table 22: Investment, competitiveness.

\begin{tabular}{|l||c|c|c||c|c|c|}
\hline \hline & \multicolumn{3}{c||}{$I N V$} & \multicolumn{3}{c|}{$\Delta U L C^{\star}$} \\
& before & during & after & before & during & after \\
\hline \hline VERY LOOSE & 14.12 & 13.60 & 13.36 & .59 & 2.23 & 5.56 \\
& $(.485)$ & $(.502)$ & $(.499)$ & $(1.30)$ & $(1.56)$ & $(1.48)$ \\
VERY TIGHT & 12.92 & 13.01 & 13.12 & 4.28 & 3.77 & 3.71 \\
& $(.413)$ & $(.342)$ & $(.343)$ & $(1.43)$ & $(1.41)$ & $(1.45)$ \\
SUCCESSFUL & 12.39 & 12.20 & 13.21 & 5.56 & -.97 & -.444 \\
& $(1.15)$ & $(.743)$ & $(.847)$ & $(2.62)$ & $(1.70)$ & $(1.46)$ \\
UNSUCCESSFUL & 13.31 & 13.55 & 13.17 & 1.70 & 3.19 & 2.49 \\
& $(.477)$ & $(.460)$ & $(.411)$ & $(1.69)$ & $(1.74)$ & $(1.72)$ \\
\hline \hline
\end{tabular}

$I N V:$ business investment/GDP in year $t, \Delta U L C^{\star}$ rate of change of unit labor costs divided by GDP-weighted average of unit labor costs of all other countries, all expressed in a common currency. 